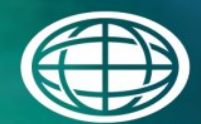

Savannah River

National Laboratory ${ }^{m}$

OPERATED BY SAVANNAH RIVER NUCLEAR SOLUTIONS

\title{
The Middle East: Domestic Sufficiency of Fossil Fuel Resources
}

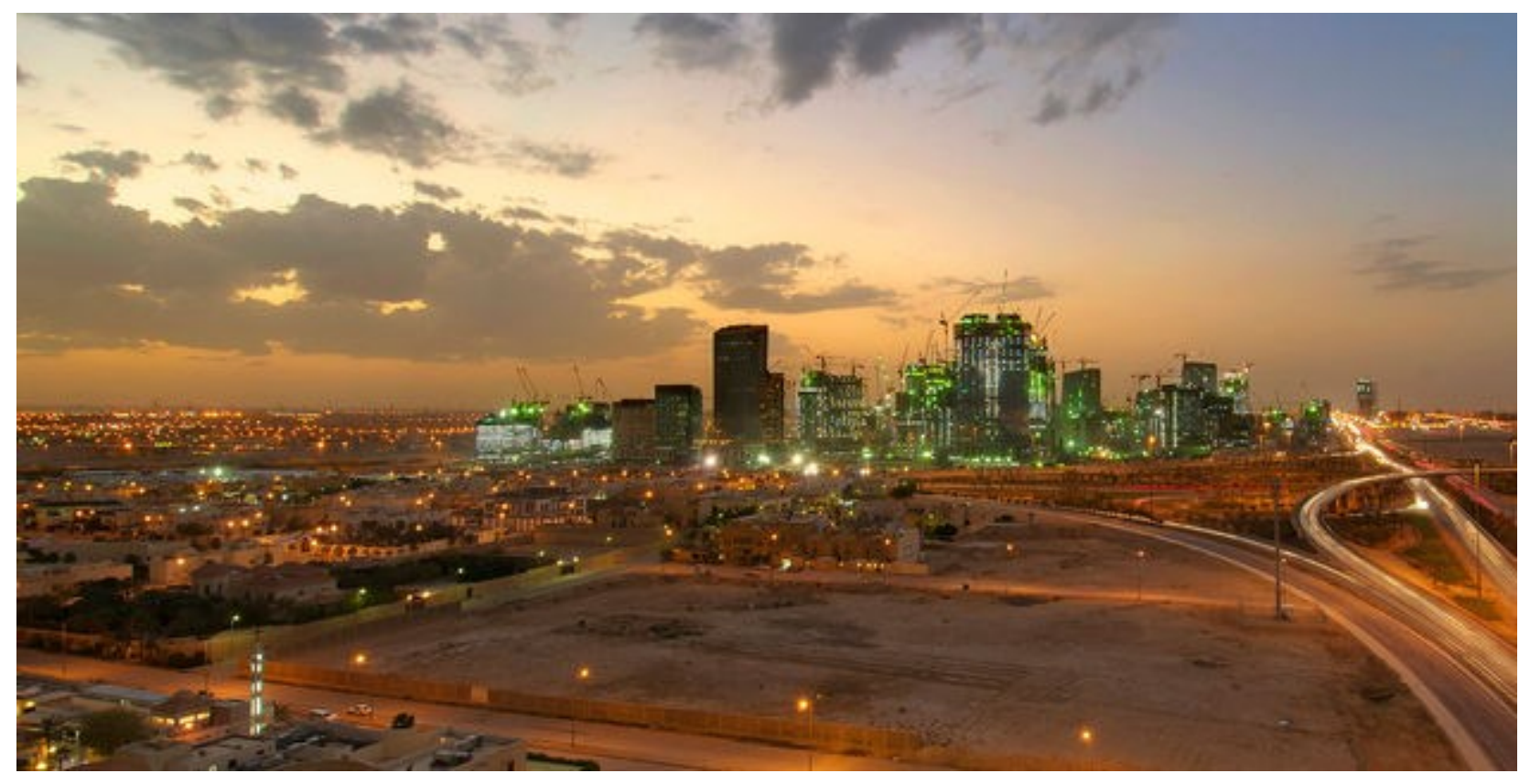

Samuel E. Kessinger and John A. Swegle

August 2016

SRNL-TR-2016-00309 
SRNL-TR-2016-00309

\section{DISCLAIMER}

This work was prepared under an agreement with and funded by the U.S. Government. Neither the U.S. Government or its employees, nor any of its contractors, subcontractors or their employees, makes any express or implied:

1. warranty or assumes any legal liability for the accuracy, completeness, or for the use or results of such use of any information, product, or process disclosed; or

2. representation that such use or results of such use would not infringe privately owned rights; or

3. endorsement or recommendation of any specifically identified commercial product, process, or service.

Any views and opinions of authors expressed in this work do not necessarily state or reflect those of the United States Government, or its contractors, or subcontractors. 


\section{The Middle East: Domestic Sufficiency of Fossil Fuel Resources}

Samuel E. Kessinger

and John A. Swegle

August 2016

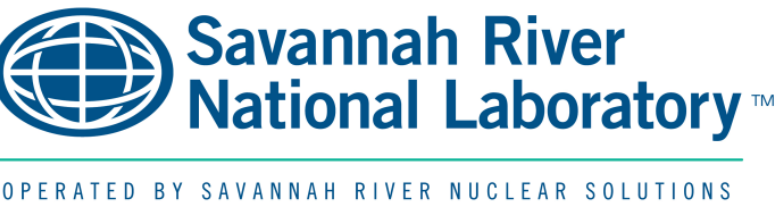

Prepared for the U.S. Department of Energy under contract number DE-AC09-08SR22470. 
SRNL-TR-2016-00309

\section{EXECUTIVE SUMMARY}

In this paper, we've compared energy production and consumption across the broader Middle East, paying special attention to three different countries:

- Saudi Arabia, one of the world's largest oil producers (second in the CIA World Factbook ranking of crude oil producing countries), with a growing population in the mid-range $\left(47^{\text {th }}\right.$ in the world, according to the CIA World Factbook, and fifth among the nations in this region), a large GDP and GDP per capita ( $15^{\text {th }}$ in the world, second in this region in GDP, and $21^{\text {st }}$ in GDP per capita in the world, just behind the US at $19^{\text {th }}$ ).

- Qatar, the world's fourth largest producer of natural gas, with a small native population (and a relatively large foreign labor contingent) that is very wealthy (with the world's highest GDP per capita, more than twice that of the US).

- Egypt, the most populous nation in the region (with the world's $16^{\text {th }}$ largest population), but relatively poor (with a GDP per capita of about a fifth that of the US and a twelfth that of Qatar); Egypt is a significant energy producer $-29^{\text {th }}$ in the world in crude oil production and $17^{\text {th }}$ in natural gas production - but production has stalled or declined in recent years, and domestic consumption has overtaken production.

Egypt's large and growing population, coupled with government subsidies for energy and encouragement of natural gas use, has outstripped its domestic fossil fuel production. Further, a government that until recently has refused to pay a profitable price to foreign natural gas producers, and that remains hobbled by debt, has resulted in a situation in which the country cannot adequately exploit its natural gas reserves.

Qatar, on the other hand, has hundreds of years of natural gas reserves. Saudi Arabia, finally, with domestic crude oil consumption that has been growing for decades at a rate that has held quite constant at about 5.3 percent per year, could begin to feel an economic pinch as consumption eats into the income derived from crude oil exports. Reducing energy subsidies to the population to help curb consumption and increasing the value-added portion of the energy sector might increase unit profits from hydrocarbons and could help alleviate the problem. 


\section{Scope Note}

The goal of our project is to investigate the effects of two factors, a growing population and the devotion of an increasing portion of a countries' economy to non-energy/non-service activities, on the future sufficiency of three key Middle Eastern nations' domestic oil and gas resources to meet each nation's needs. More specifically, this project focuses on whether the growth of domestic consumption will consume all, or an outsized fraction, of their Gross Domestic Product (GDP). In the long run, beyond the scope of this study, this investigation could be used to support a follow-on study of the credibility of claims by some nations in the Middle East that nuclear energy has to be considered as a major power source to preserve their fossil-fuel resources, either as an export commodity or as the foundation of a value-added chemical industry.

\section{Determination of Relevant Countries}

To determine the geographic scope of this study, we took into account both a country's geographic location and its status as a fossil fuel producer. This investigation addresses the countries contained within a somewhat generalized "Middle East;" however, not all countries that reside in this region are fossil fuel producers. In order to create a more concise list of countries to analyze, we looked at the production and consumption rates of crude oil and natural gas. After determining which countries in and near the geographic region were fossil fuel producers, the country Turkmenistan was included because of its natural gas production, while Armenia, Israel, Jordan, Lebanon, Syria, and Turkey were eliminated. Taking both geographical placement and status as a fossil fuel producer into account, we ultimately considered the following list of countries: Azerbaijan, Egypt, Iran, Iraq, Kuwait, Oman, Qatar, Saudi Arabia, Syria, Turkmenistan, United Arab Emirates, and Yemen, as shown in Figure 1. Of these 12 countries; we have chosen to analyze Saudi Arabia, Qatar, and Egypt more closely. We chose these three countries for closer inspection because of both the unique features of their oil and gas consumption and their drastically different per-capita comparisons of GDP ${ }^{1}$ vs Energy Use.

\section{Background for the Overall Region}

With an overall region established, we consider this group of countries more closely by comparing four parameters for each nation: GDP (Figure 2), GDP per Capita, Population (Figure 3), ${ }^{2}$ and Energy Use per Capita. ${ }^{2}$ Even though these four parameters by no means provide for exhaustive comparison, they allow us to easily form a first-order comparison and ranking of the countries. GDP is an integrated measure of a country's total economy and allows us to rank countries in some overall sense according to their weight and influence in the regional and global economy. Whereas GDP is a measure of "national wealth," GDP per Capita is in some sense an indicator of "individual wealth," or at least possible average individual wealth before one factors in income distribution, adjusted to the global standard dollar for easy comparison. This value can also be used to represent the productivity and economic performance of a nation's population. Energy Use per Capita is the average amount of energy each individual uses; this value is created by dividing the total national energy usage by the nation's population. This value has been shown to correlate with GDP per Capita (see Figure 4) and is therefore related to the average standard of living of a population.

1 When we compare GDP between countries, we use values adjusted according to Purchasing Power Parity such as determined, for example, by the World Bank's International Comparison Program,

http://web.worldbank.org/WBSITE/EXTERNAL/DATASTATISTICS/ICPEXT/0,,contentMDK:22377119 menuPK:678210 0 pagePK:60002244 piPK:62002388 theSitePK:270065,00.html.

2 Central Intelligence Agency, CIA World Factbook, accessed 12 July 2016, https://www.cia.gov/library/publications/theworld-factbook/ 


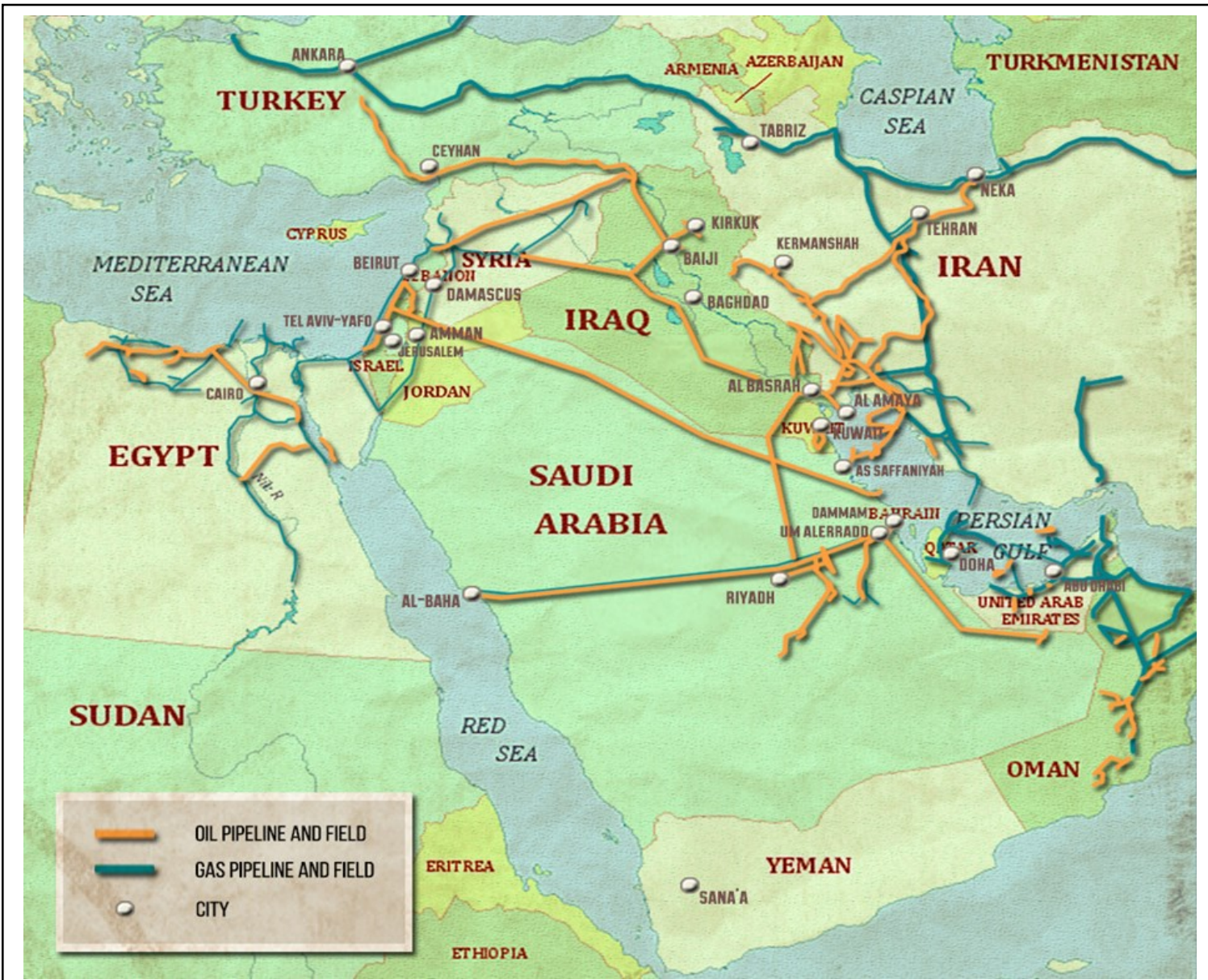

Figure 1. Our region of interest, although we do not include Armenia, Israel, Jordan, Lebanon, Syria, and Turkey.

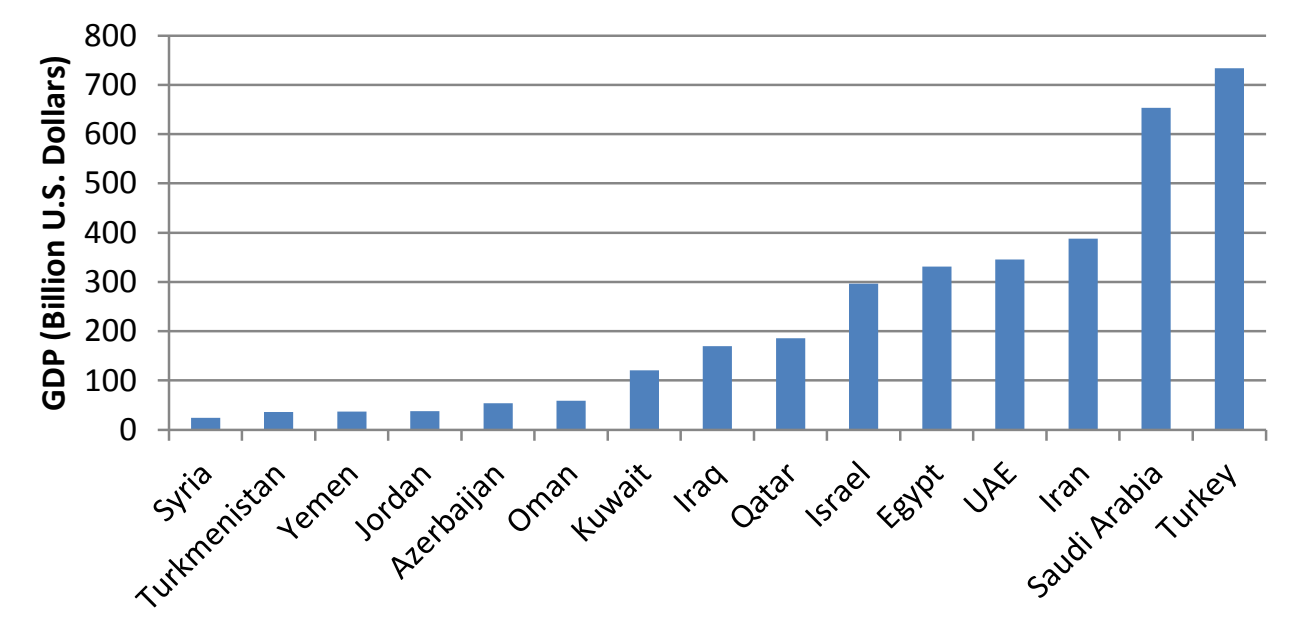

Figure 2. GDP of nations in the region (Israel, Jordan, Syria, and Turkey included for comparison). 


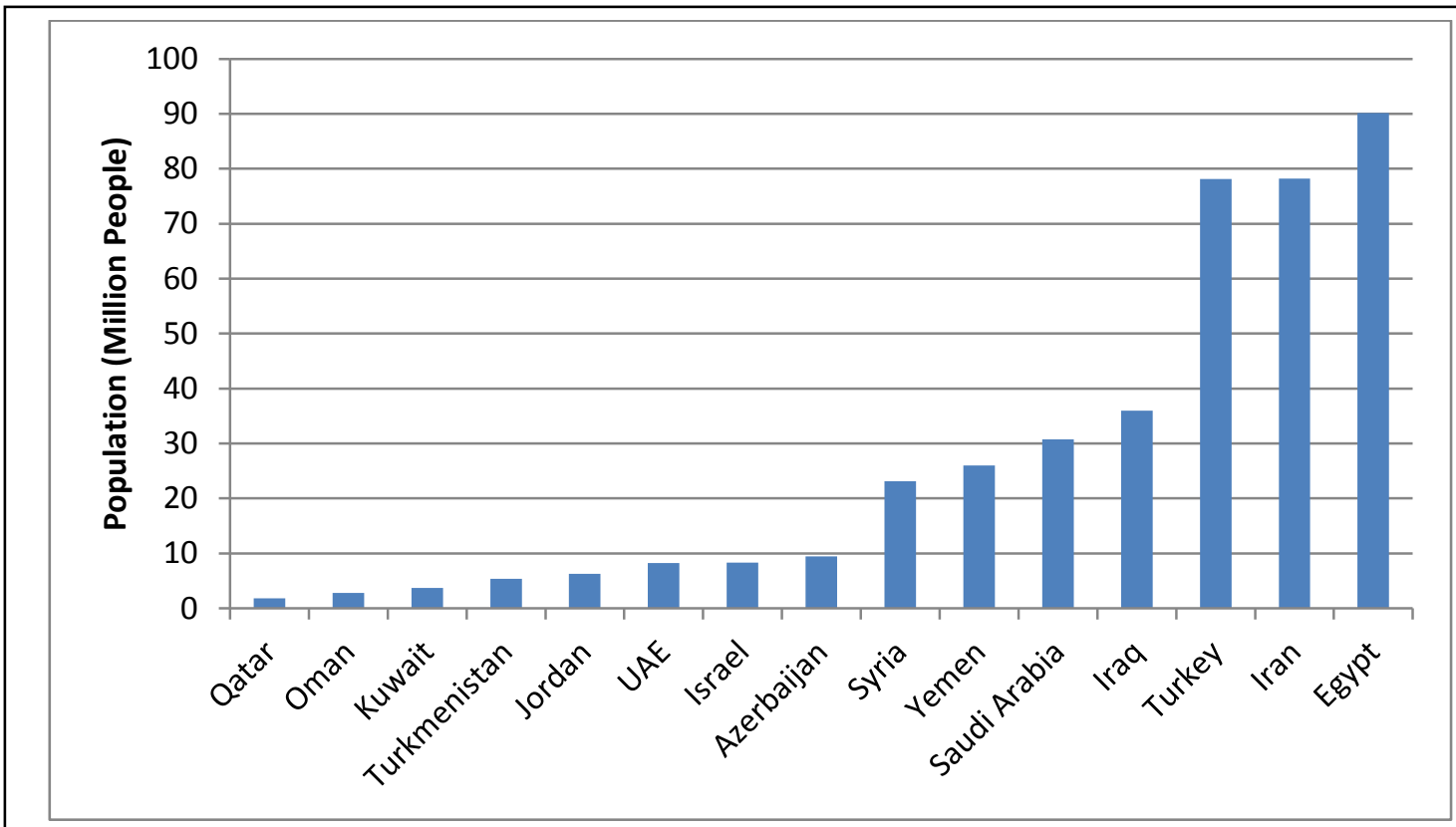

Figure 3. Populations of nations in the region (Israel, Jordan, Syria, and Turkey included for comparison).

\section{Investigation of Specific Countries}

We have chosen to investigate three countries more deeply: Saudi Arabia, Qatar, and Egypt. We focus on these countries because of the variety in their consumption of fossil fuels ${ }^{3}$ and economic systems. To illustrate the differing fossil fuel consumption between these three nations, we compare historic fossil fuel production and consumption for each country in the following section. These data point to the differing rates of each country's production and consumption of crude oil and natural gas, and they reveal trends that have been evident since the 1970s. All indicate the steadily increasing rates of fossil fuel consumption that are the root, and provide a measure of the urgency, of the concern surrounding the devotion of these nations' main product, fossil fuels, to domestic use rather than export.

\section{Past to Present}

\section{Overview of Production and Consumption}

Historically, the Middle East has been a major fossil fuel producer. Production in this region ramped up around 1965 and has continued and increased since then. Crude oil and natural gas are both extracted by the countries in this area of the world. Factors such as political instability, oil and gas prices, and the local and global economies can affect production of fossil fuels, and these factors are visible in the large annual fluctuations in fossil fuel production observed.

Consumption of fossil fuels in the Middle East has been steadily increasing as long as records have been kept. This steady growth can be attributed to a number of factors including population growth,

3 British Petroleum, Statistical Review of World Energy, accessed 14 July 2016,

http://www.bp.com/en/global/corporate/energy-economics/statistical-review-of-world-energy.html. 
SRNL-TR-2016-00309

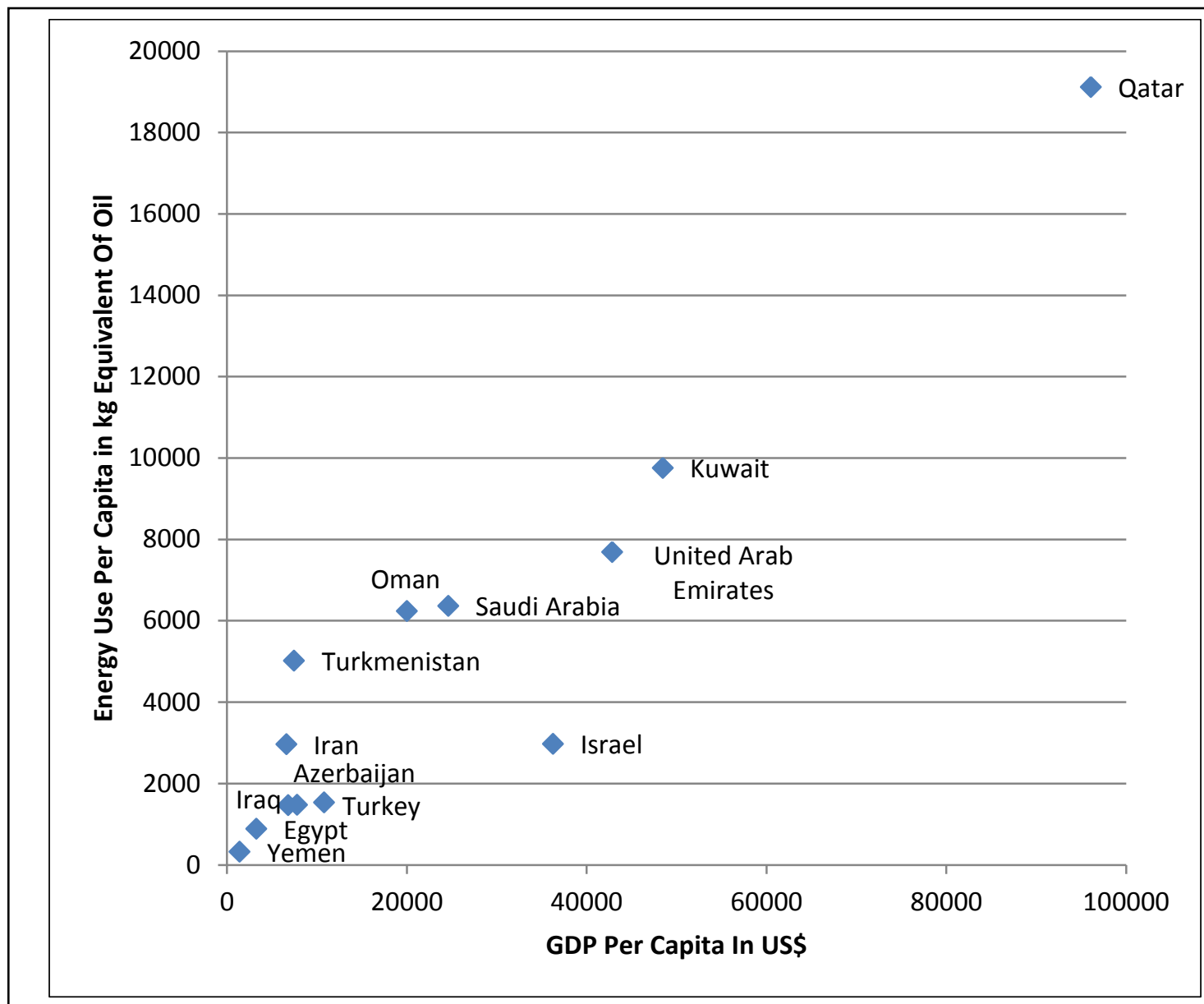

Figure 4. Energy Use per Capita vs GDP per Capita for nations in the region. To compare, for the US the figures are $6,794 \mathrm{~kg}$ Equivalent of Oil (2012) and US\$53,042 (2013).

development of fossil-fuel-based chemical industries, and an increasing quality of living. Both Saudi Arabia and Qatar are considered developed nations, with strong service economies, while Egypt is still a growing nation that has yet to reach the status of a developed country. Fossil fuels are consumed within these countries for a number of reasons, such as generation of electrical power for lighting and air conditioning, fueling automobiles (both refined crude oil and compressed natural gas, or $\mathrm{CNG}$, can be used for this), ${ }^{4}$ desalination (to produce potable water), and waste water treatment.

This reliance on fossil fuels to provide essentially all the power to run each country can be seen as a slippery slope. These Middle Eastern nations all have increasing levels of primary energy consumption some more than others - and projected hydrocarbon energy demand in each case appears to be headed for unsustainable levels at which domestic consumption outstrips production. The natural response, when a country senses the depletion of a fossil fuel deposit that is so integral to the country's economy, is to curtail consumption and/or to curtail production. For countries so dependent on fossil fuels for power generation, this change in consumption/production faces many challenges, ranging from the construction of alternative energy sources (for example, nuclear, wind, hydro-electric, geothermal, solar) to rethinking

4 "Egypt: major state investment to convert 2,000 vehicles to natural gas," NGV Journal, 28 January 2015, http:/www.ngvjournal.com/egypt-major-state-investment-to-convert-2000-vehicles-to-natural-gas/ 
and redesigning their power system (more efficient two-stage turbines, CNG generators, redesign of electrical grid) to increase efficiency. Without real, tangible changes to the consumption habits of these Middle Eastern nations, their consumption, if left unchecked, runs the risk of increasing to a level equal or larger than these nations' fossil fuel production. It is important to remember that fossil fuels are not an infinite resource; theoretically all finite resources will be consumed. The fear of depleting a fuel resource is not reason enough to end the fuels' use, instead the fear of total consumption forces the users to plan ahead and prepare for the end.

\section{$\underline{\text { Saudi Arabia: Production and Consumption }}$}

Fossil fuel, specifically crude oil, production in Saudi Arabia began to be exploited commercially, on a large scale, around 1960, marking the beginning of the kingdom's dependence on its most lucrative export. Only oil, and not natural gas, is being exported as of this time. All natural gas produced within the kingdom is used domestically.

When OPEC was created in 1960, Saudi Arabia was one of the five original founding nations, ${ }^{5}$ along with Iran (during the reign of the Shah), Iraq (pre-Saddam Hussein), Kuwait, and Venezuela. After the creation of OPEC, and subsequently Saudi Arabia's link to the fossil fuel production of the other OPEC nations, crude oil production began to fluctuate dramatically. As seen in Figure 5 and Figure 6, which show Saudi Arabian oil and gas production and consumption, as well as Primary Energy Consumption (Primary Energy Consumption is defined in terms of primary energy sources, which British Petroleum defines as any publicly-traded fuel, to include hydrocarbons, nuclear, and renewable)s. ${ }^{6}$ These quantities are

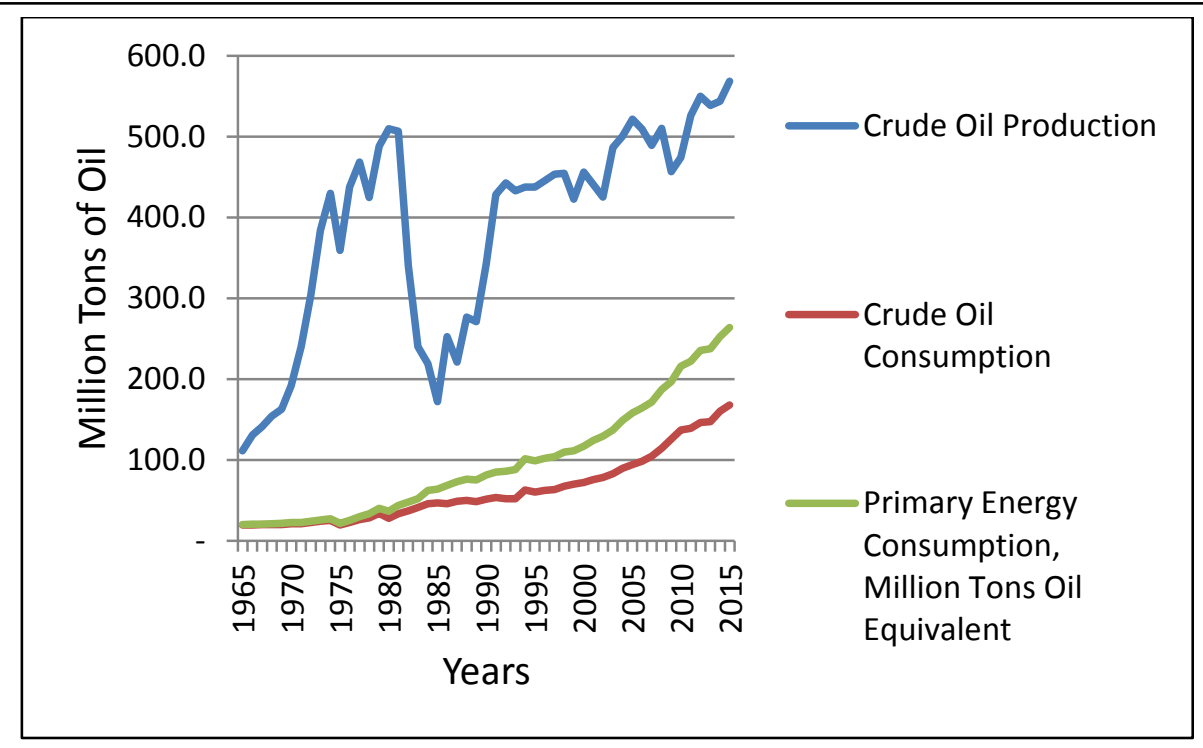

Figure 5. Saudi Arabia's crude oil production and consumption, and its primary energy consumption

5 The Organization of Petroleum Exporting States (OPEC), "Brief History,” accessed 1 August 2015, http://www.opec.org/opec_web/en/about_us/24.htm

6 British Petroleum, "Primary Energy - 2015 in Review," Statistical Review of World Energy, accessed 14 July 2016 , http://www.bp.com/en/global/corporate/energy-economics/statistical-review-of-world-energy/primary-energy.html 
expressed in terms of their energy content, given in units of tonnes of oil equivalent, defined as $10^{7}$ kilocalories, or 41.868 gigajoules. $^{7}$ These fluctuations were a visible sign of the influence of many exogenous factors.

Since about 1970, Saudi Arabian crude oil production has leveled out; however it still fluctuates largely in relation to many other factors. Saudi Arabian crude oil consumption has steadily been increasing on average since about 1990.

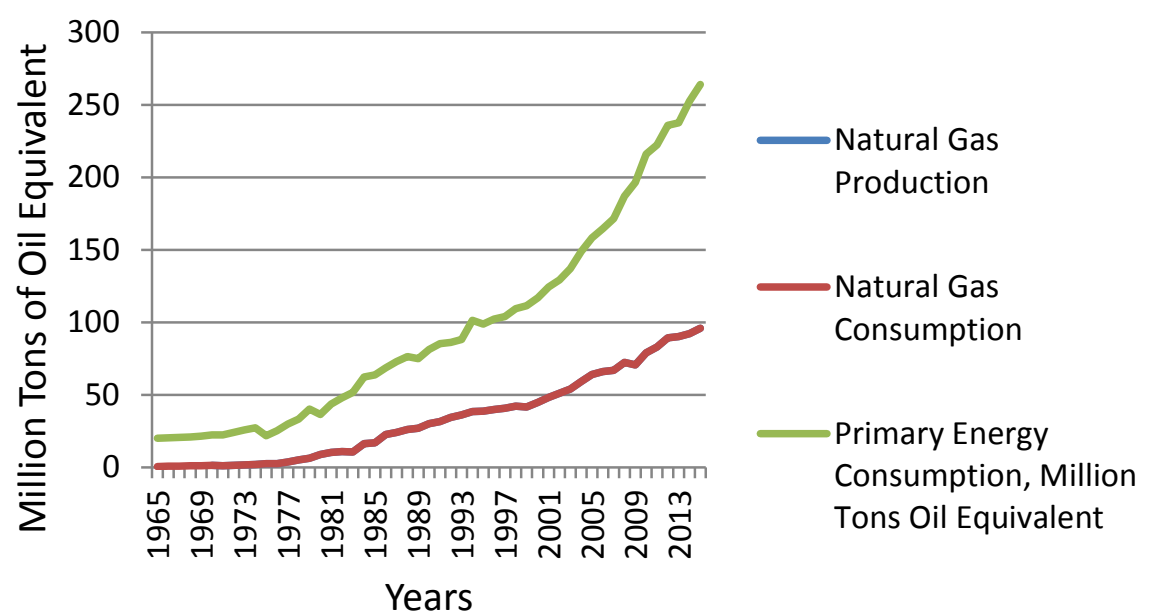

Figure 6. Saudi Arabia's natural gas production and consumption (which coincide), and its Primary Energy Consumption

Saudi Arabian fossil fuel consumption appears to be an example of a nation approaching a turning point. The kingdom has experienced an increase in both crude oil and natural gas consumption; the sum of the increasing crude oil and natural gas consumption is essentially equal to the nation's increasing Primary Energy Consumption. Historically, this nation has done nothing but increase the domestic consumption of their largest and most economically valuable resource. As previously stated, Saudi consumption is essentially a real-life example of the possible over-consumption scenario described earlier. Without a change in Saudi consumption, that change could come from a number of the different avenues previously mentioned; the kingdom will begin to purchase fossil fuels instead of selling fossil fuels. ${ }^{8}$

\section{Qatar: Production and Consumption}

Fossil fuel production in Qatar differs slightly from the Saudis' production. Instead of crude oil being Qatar's main export, natural gas holds that title. Much like Saudi Arabia's production, Qatari production, of both natural gas and crude oil, fluctuates substantially with many different factors. See Figure 7 and Figure 8 for Qatar's oil and gas production and consumption, as well as Primary Energy Consumption. Historically, Qatari fossil fuel production has been exploited since about the 1960's; however, up until

7 “Energy Supply," OECD Factbook, Economic, Environmental, and Social Statistics, 2015-2016, p. 98, http://www.oecdilibrary.org/docserver/download/3015041e.pdf?expires=1477594682\&id=id\&accname=guest\&checksum=6002A210FAE849 C196E63B2C2E52093B

8 Arash Farnoosh, Frederic Lantz, and Jacques Percebois, "Electricity generation analyses in an oil-exporting country: Transition to non-fossil fuel based power units in Saudi Arabia," Energy, 69, 299-308 (2014. 
1995, the yearly rate of increase of production had been minimal compared to 1995 onward. In the 20 years since 1995, Qatari natural gas production is about 101/2 times larger than it was before 1995, and crude oil production is about four times larger now compared to 1995. The production of both fossil fuels began to increase at high rates, relative to pre-1995 levels, coinciding with a shift of power in Qatari leadership and the exploitation of a natural gas field that began exporting in 1996.

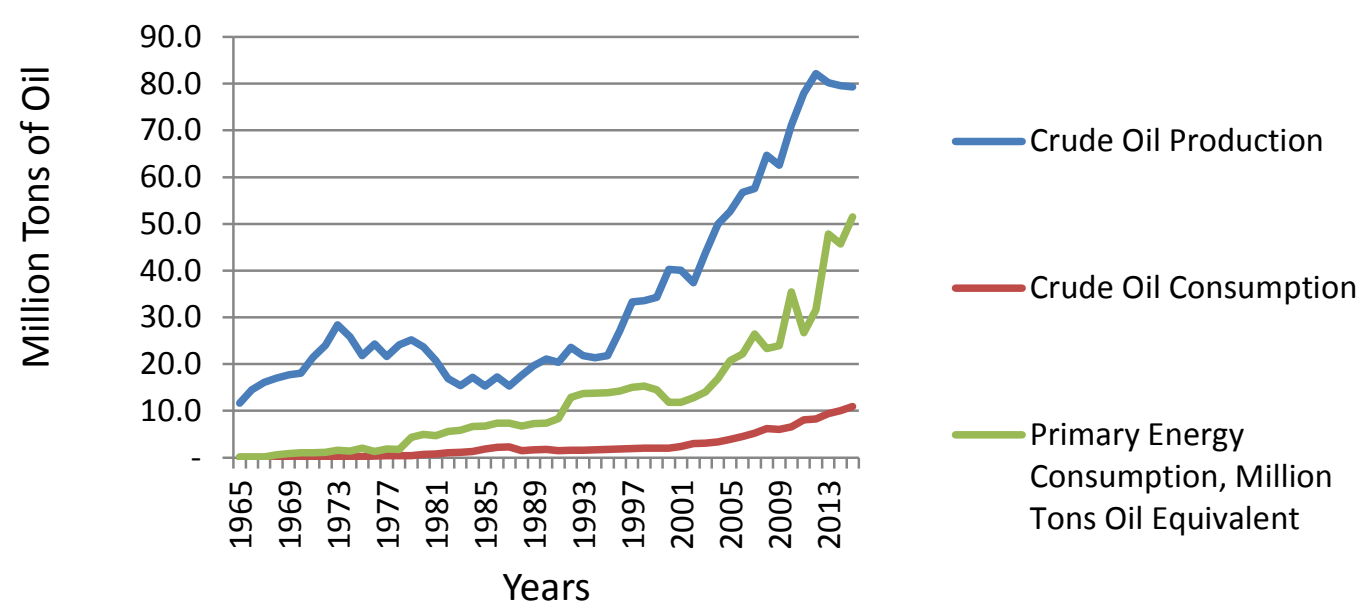

Figure 7. Qatar's crude oil production and consumption, and its Primary Energy Consumption

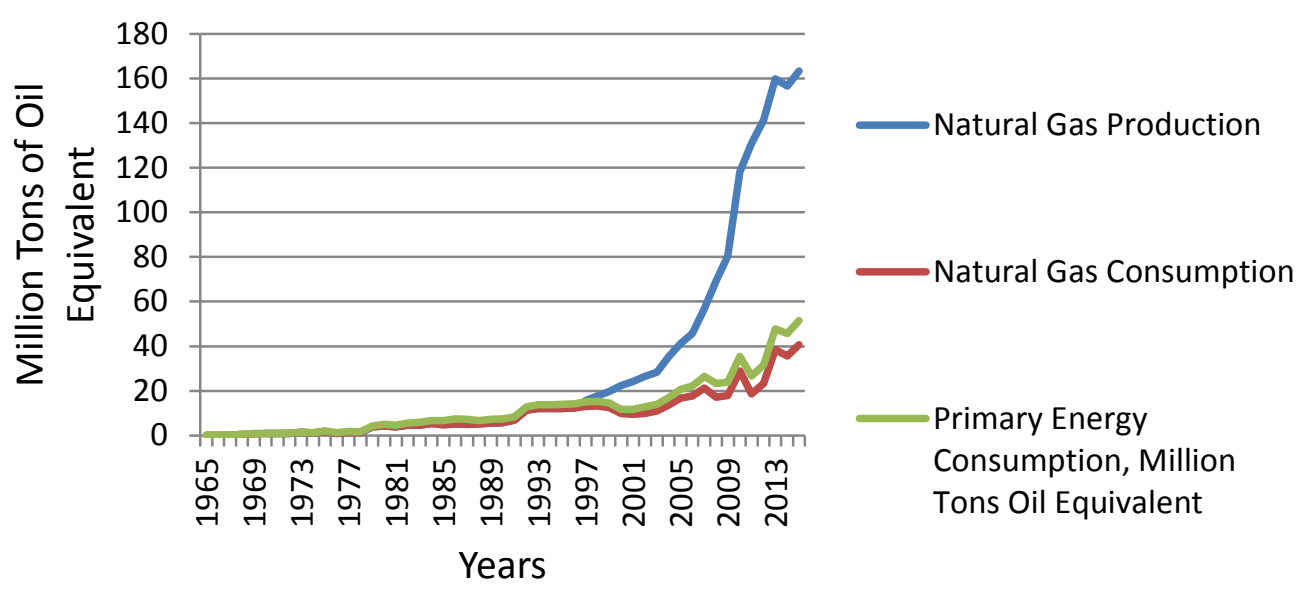

Figure 8. Qatar's natural gas production and consumption, and its Primary Energy Consumption

Qatari consumption, though not as consistent as Saudi Arabia's, is also on track to fall into the trap of over-indulging domestically; however, Qatar's vice is not crude oil. Instead, they keep the air conditioner on using mostly natural gas (as shown in Figure 8 especially). As previously stated- when discussing Qatari fossil fuel production, the exploitation of their natural gas reserves have only recently begun to ramp up. This relatively recent increase in fossil fuel production also coincides with the large, and concurrent, increases of both fossil fuel consumption and Primary Energy Consumption. This quickly growing demand for fossil fuels is just as economically dangerous as Saudi Arabia's situation; however, 
this nation has not yet reached a point as pivotal as that of Saudi Arabia. Due to the short time that Qatar has been exploiting its resources at such a high rate, relative to Saudi production that began in the 1960's, Qatar has not yet depleted their main fuel source as drastically as other nations in the region. This lack of urgency regarding the depletion of the nation's reserves does not protect the country from its own growing domestic consumption; in reality Qatar must also implement changes to protect their nation from the future depletion of their fossil fuel resources. Qatari fossil fuel consumption, like all fossil fuel consumption, is unsustainable; however Qatar is not in as dire straits as Saudi Arabia.

\section{Egypt: Production and Consumption}

Fossil fuel production in Egypt differs slightly from both Saudi Arabia's mainly crude oil based system and Qatar's natural gas based system. Instead of being biased toward a certain fuel, the split in its usage of oil and natural gas is relatively equal. See Figure 9 and Figure 10 for Egypt's oil and gas production and consumption, as well as Primary Energy Consumption. Egypt, as a nation, does not possess a large

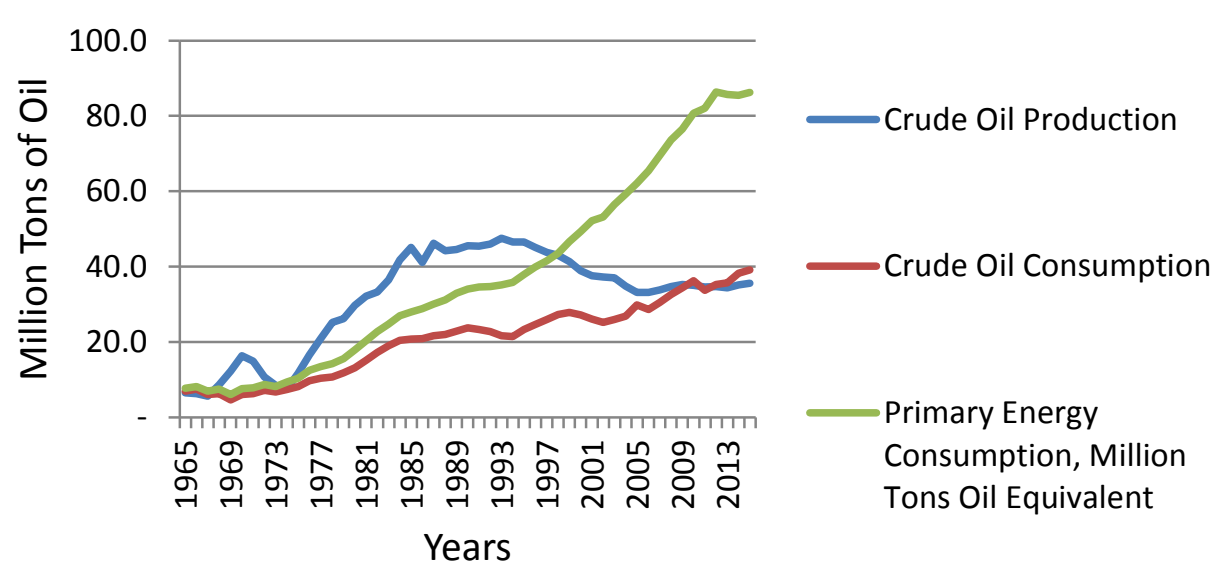

Figure 9. Egypt's crude oil production and consumption, and its Primary Energy Consumption

crude oil field, and this is visible when looking at the historic crude oil production graphs. Egypt began to take advantage of this resource, crude oil, around 1965 and since then has continued to produce oil. Egyptian crude oil production peaked around 1993 and then abruptly decreased; it is now finally beginning to level out and slightly increase again. Crude oil production in Egypt has slowed, compared to the 1990s; however, this slow rise has not tracked with natural gas production. Egyptian natural gas production spiked in 2004 and reached peak production in 2009. Since 2009 production has decreased, and as of 2015 it is still on the decline. This decline is due in large measure to an historical unwillingness to pay foreign producers a price that would make production profitable, as well as the substantial unpaid debt that Egypt owes foreign producers, who are reluctant to provide further loans to Egypt. ${ }^{9}$ Fossil fuel production in Egypt has also fluctuated; these changes are the result of exogenous factors, including political instability and changes in the world economy.

9 “Egypt,” U.S. Energy Information Administration, June 2, 2015, accessed 15 August 2016, https:// www.eia.gov/beta/international/analysis.cfm?iso=EGY. 


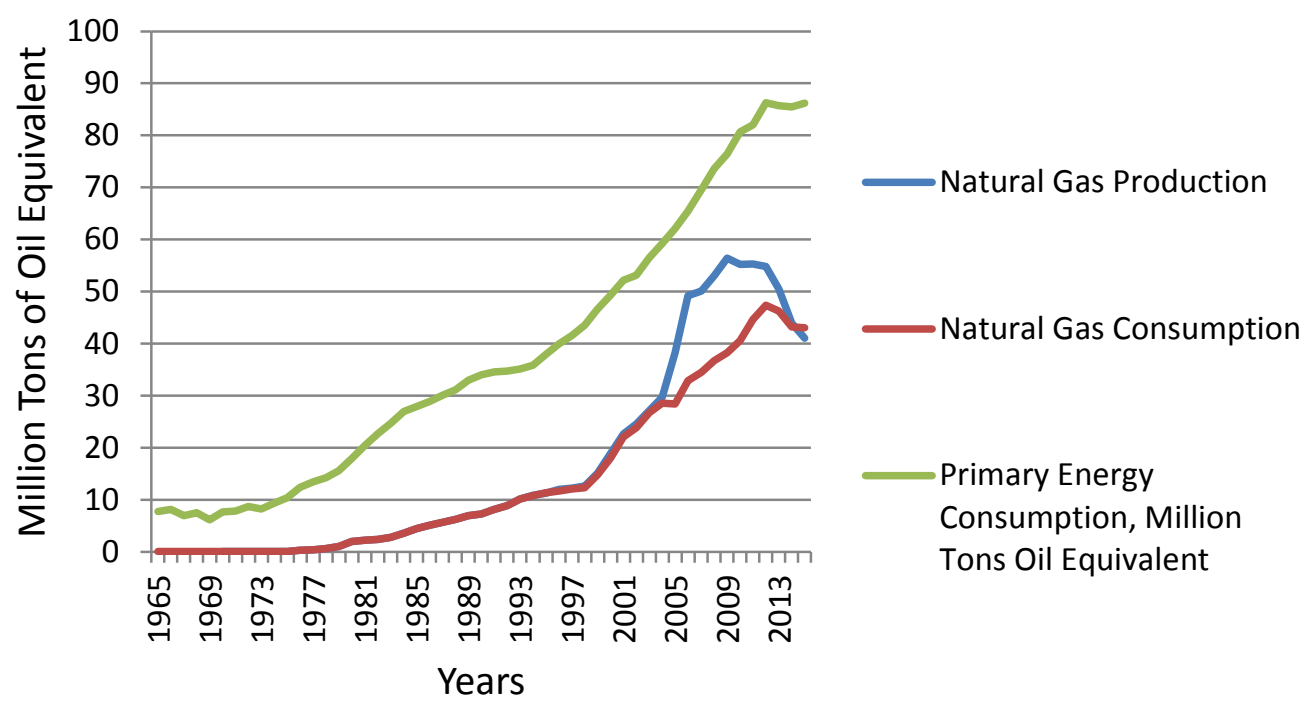

Figure 10. Egypt's natural gas production and consumption, and its Primary Energy Consumption

Egyptian consumption follows the same trend as both Qatar and Saudi Arabia; however, Egyptian fossil fuel consumption has a distinct characteristic worthy of special attention. Instead of having an energynct characteristic worthy of special attention. Instead of having an energy system that is partial to either crude oil fuels or natural gas, Egypt has a relatively diversified fuel consumption portfolio. Egyptian fossil fuel consumption is about $46 \%$ crude oil, $50 \%$ natural gas, and $4 \%$ renewables and hydroelectric. This diversified energy generating system allows Egypt to stay away from depleting a single resource in order to power their nation; however, this diverse use of fuels does not save Egypt from the same fate that will plague the others in the Middle East, as shown by the overtaking of production by consumption.

\section{$\underline{\text { Summarizing Primary Energy Consumption by Energy Source }}$}

Having discussed energy consumption in each of the three countries, we summarize the points about each country's primary energy sources in Figure 11 with a pie chart for each country.
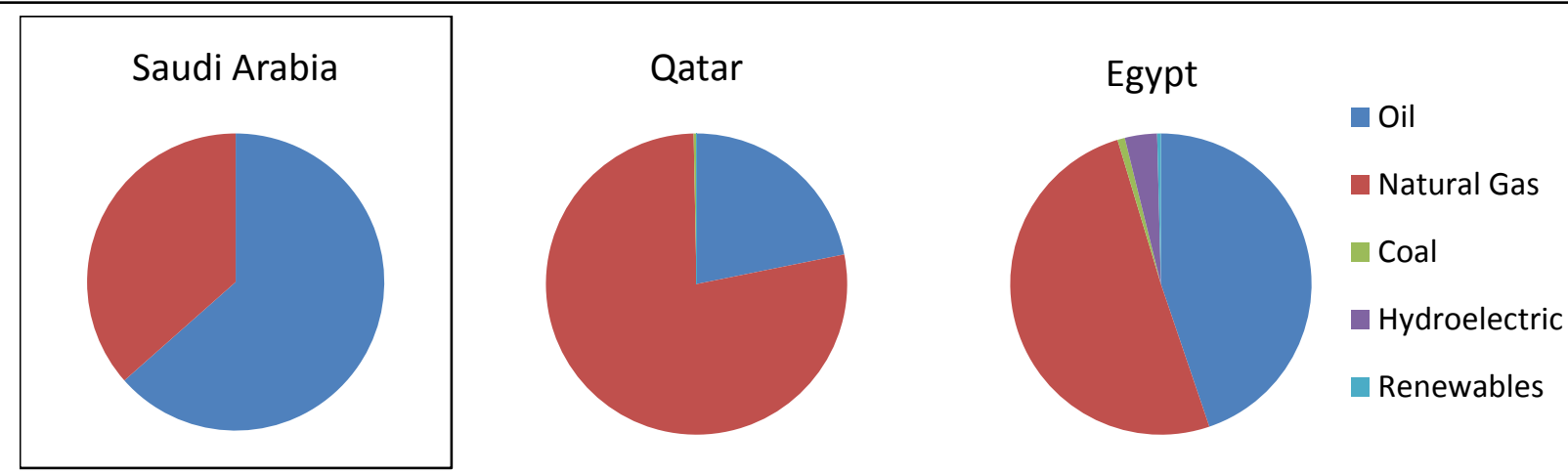

Figure 11. Breakdown of different Primary Energy Sources in Saudi Arabia, Qatar, and Egypt 


\section{Looking To the Future}

Having looked from the past to the present, we next examine the historical production and consumption trends. We will use these data to make two simple estimates of the future relationship between production and consumption, the first for the region overall and the second focused only on Saudi Arabia.

\section{Overall Region - Assuming a Constant Rate of Depletion}

First, looking at the region as a whole, we assume a constant rate of depletion - the rate at which these resources are consumed - in an attempt to estimate how long current reserves could last. We estimate the rate of depletion by taking a ten-year average of production during the period 2005-2015, calculating separate depletion rates for oil and gas. This approach, of course, does not account for increasing consumption, as we have seen has been the case in varying degrees for Saudi Arabia and Qatar, with respect to both oil and natural gas. However, as we have also seen, consumption has not increased so rapidly for Egypt in recent years. Further, we do not account for potentially unexploited resources in any of these countries that could expand reserves. Thus, this is a very approximate, first-cut estimate.

British Petroleum data for proven crude-oil and natural-gas reserves ${ }^{10}$ and a ten-year average for production for our countries of interest are shown in Table 1. Note that Kuwait and Israel are not at this

\begin{tabular}{|c|c|c|c|c|}
\hline & $\begin{array}{l}\text { Crude Oil Reserves } \\
\text { (Billion Barrels) }\end{array}$ & $\begin{array}{l}\text { Avg Yearly Crude } \\
\text { Oil Production } \\
\text { (Million Barrels/Yr) }\end{array}$ & $\begin{array}{c}\text { Natural Gas } \\
\text { Reserves (Trillion } \\
\text { Cubic Feet) }\end{array}$ & $\begin{array}{l}\text { Avg Natural Gas } \\
\text { Production (Billion } \\
\text { Cubic Feet/Yr) }\end{array}$ \\
\hline Azerbaijan & 7.0 & 306.6 & 40.6 & 475.2 \\
\hline Egypt & 3.5 & 258.8 & 65.2 & $1,952.9$ \\
\hline Iran & 157.8 & $1,507.1$ & $1,201.4$ & $5,239.7$ \\
\hline Iraq & 143.1 & 986.2 & 130.5 & 42.8 \\
\hline Israel & -- & -- & 6.4 & -- \\
\hline Kuwait & 101.5 & $1,040.3$ & 63.0 & -- \\
\hline Oman & 5.3 & 308.4 & 24.3 & 475.2 \\
\hline Qatar & 25.7 & 584.4 & 866.2 & $1,034.5$ \\
\hline Saudi Arabia & 266.6 & $3,980.7$ & 294.0 & $3,100.0$ \\
\hline Syria & 2.5 & 103.3 & 10.1 & 201.3 \\
\hline Turkmenistan & 0.6 & 80.3 & 617.3 & $2,096.7$ \\
\hline UAE & 97.8 & $1,181.9$ & 215.1 & $1,824.0$ \\
\hline Yemen & 3.0 & 94.5 & 9.4 & 144.8 \\
\hline
\end{tabular}

time extracting natural gas for use. From these data, we estimate the years that proven reserves of each resource will last at a production rate for each that is averaged over the last decade. The results are shown in Table 2. Several features are notable in the table. Iran, Iraq, and Kuwait appear to have about 100 years or more of crude-oil reserves, although Iranian and Iraqi production have been depressed by sanctions and war. Saudi Arabian crude-oil reserves appear to be lower than one might initially expect; however, the

10 British Petroleum, Statistical Review of World Energy, accessed 14 July 2016,

http://www.bp.com/en/global/corporate/energy-economics/statistical-review-of-world-energy/primary-energy.html 
Kingdom's enormous production affects that value strongly. Further, undiscovered reserves, population growth, and domestic consumption could change that picture in competing ways.

\begin{tabular}{|c|c|c|}
\hline & $\begin{array}{l}\text { Estimated Years of } \\
\text { Crude-Oil Reserves }\end{array}$ & $\begin{array}{l}\text { Estimated Years of } \\
\text { Natural-Gas Reserves }\end{array}$ \\
\hline Azerbaijan & 23 & 85 \\
\hline Egypt & 13 & 33 \\
\hline Iran & 105 & 229 \\
\hline Iraq & 145 & 3,051 \\
\hline Kuwait & 98 & -- \\
\hline Oman & 17 & 51 \\
\hline Qatar & 44 & 837 \\
\hline Saudi Arabia & 67 & 95 \\
\hline Syria & 24 & 50 \\
\hline Turkmenistan & 7 & 294 \\
\hline UAE & 83 & 118 \\
\hline Yemen & 32 & 65 \\
\hline
\end{tabular}

With regard to natural-gas reserves, Iraq's value appears to be enormous; however, natural-gas production in war-torn Iraq is extremely low at the present time. Reserves really are quite large, on the other hand, for Iran (recalling the possibility of sanctions-depressed production that pushes their numbers up), Qatar, and Turkmenistan.

\section{Saudi Arabia - Extrapolating from Past Consumption}

Second, in addition to assuming constant production as we did in the previous section, for the particular case of Saudi Arabia, we assumed that yearly domestic ${ }^{11}$ oil consumption C, measured in millions of tonnes per year, grows at a constant rate per year, $\Delta C$. In this case, consumption in the $n^{\text {th }}$ year, Year (n), is related to that of the previous year, Year (n-1), by

$$
\mathrm{C}[\text { Year }(\mathrm{n})]=(1+\Delta \mathrm{C}) * \mathrm{C}[\text { Year }(\mathrm{n}-1)]
$$

If we start with consumption in 2015 as Year (0), then for $\mathrm{n}=1,2,3, \ldots$,

$$
\text { Year }(n)=2015+n \text {, }
$$

Thus, Year (1) = 2016, for example. Combining Equations (1) and (2), we get

$$
\mathrm{C}[\operatorname{Year}(\mathrm{n})]=(1+\Delta \mathrm{C})^{\mathrm{n}} * C(2015)
$$

To complete our model, we use the data to find that $\mathrm{C}(2015)=168.1$ million tonnes of crude oil per year. Next, to find $\Delta \mathrm{C}$, we choose to go back in time to 1975 (i.e., 39 years) to calculate

11 We emphasize the point about domestic consumption because, in the previous section, we considered crude oil production for both domestic consumption and export. 


$$
\left[\frac{\mathrm{C}(2015)}{\mathrm{C}(1975)}\right]^{1 / 39}-1=\Delta \mathrm{C}
$$

Since $C(1975)=19.3$ million tonnes of crude oil per year, we find $\Delta C=0.05295$. Thus, extrapolating from 2015 onward and simplifying by writing Year (n) = Year (for Year > 2015), we get

$$
\mathrm{C}(\text { Year })=168.1 *(1.05295)^{\mathrm{Year}-2015} \text { million tonnes of crude oil per year }
$$

In Figure 12, we compare the model in Equation 5, adjusted for a starting year of 1975 (using the same

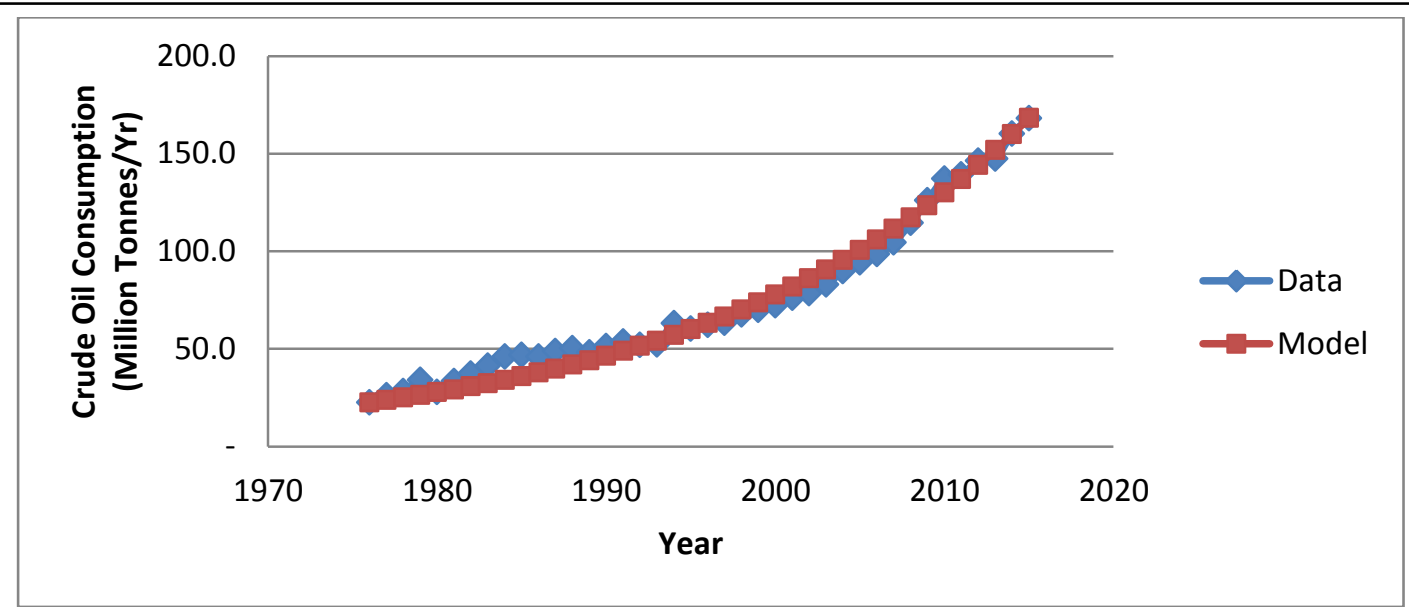

Figure 12. Comparison of a constant-growth-rate model with data for domestic crude oil consumption in Saudi Arabia over the period 1975-2015.

growth rate, $\Delta \mathrm{C}=0.05295$, which we determined using data over the interval 1975-2015), to the data over the period 1975-2015. We can see that within the fluctuations of the data, our expression provides a good approximation over this forty-year interval. To extrapolate, we use the expression in Equation 5 to determine the yearly domestic consumption out to 2035, a twenty-year interval, as well as the cumulative domestic consumption, the running sum of the yearly consumption. This is shown in Figure 13.

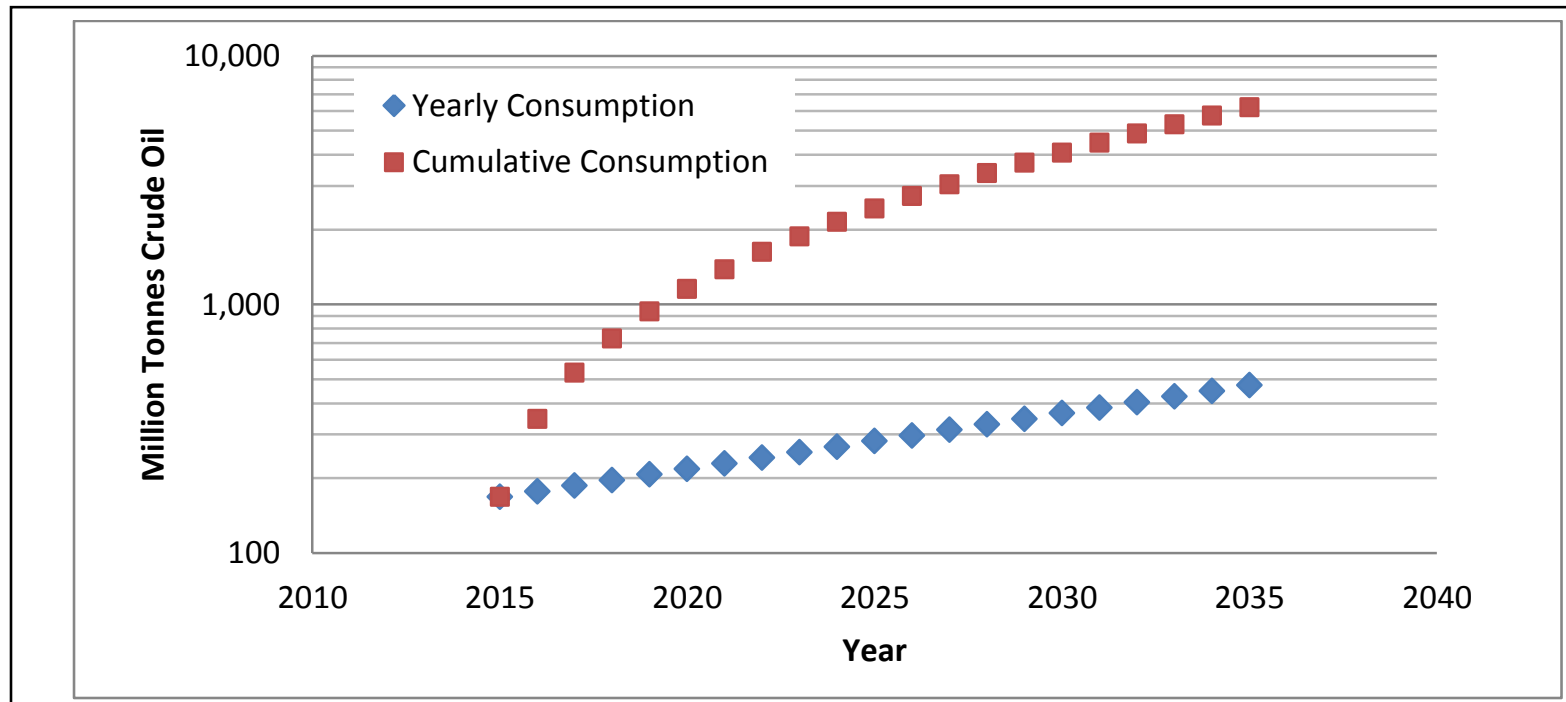

Figure 13. Based on Equation 5, predicted yearly and cumulative domestic consumption of crude oil for Saudi Arabia. 
According to Equation 5, by 2035 the yearly domestic consumption would rise to 472 million tonnes of crude oil per year, almost three times that in 2015. By 2035, the cumulative domestic consumption over our twenty-year period is predicted by this model to be 6,207 million tonnes of crude oil. Converting units from Table 1 ( 1 tonne $=7.15$ barrels), we find that our model predicts that Saudi domestic consumption of crude oil in 2035 would be about 85 percent of the ten-year production average in Table 1, while cumulative domestic consumption during the years 2015-2035 would represent almost 17 percent of Saudi Arabia's known reserves as of 2015.

We attribute the growth of Saudi Arabian domestic consumption over the period 1975-2015 to growth of the population and growth of GDP during that period. In fact, Figure 4 indicates that domestic consumption can be expected to grow with population and GDP per capita, or with the population and the relative wealth of the population, as measured by GDP per capita. Looking solely at the effect of population growth, we compute the correlation function for crude oil domestic consumption and population:

$$
\text { Correlation (Consumption, Population) }=\frac{\sum_{1965}^{2015}\{[\mathrm{C}(\text { Year })-<\mathrm{C}>][\mathrm{P}(\text { Year })-<\mathrm{P}>]\}}{\sqrt{\left.\sum_{1965}^{2015}[\mathrm{C}(\text { Year })-<\mathrm{C}>]^{2}\right] \sum_{1965}^{2015}\left[[\mathrm{P}(\text { Year })-<\mathrm{P}>]^{2}\right]}}
$$

In this equation, the sums are over the years $1965-2015, \mathrm{C}$ is yearly domestic consumption, $\mathrm{P}$ is population, and $\langle\mathrm{C}>$ and $\langle\mathrm{P}>$ are the averages of domestic consumption and population over that time period, respectively. We find that domestic consumption and population are highly correlated over this time period, with a value of 0.956 for the expression in Equation 6 (with 1.0 indicating perfect correlation).

However, we find that our model of constant yearly growth for domestic consumption does not apply as well to population growth over the period 1975-2015. Proceeding with population in the same way that we did with domestic consumption, assuming a constant yearly growth, we find that to fit the population growth over that period, the population growth rate would be $\Delta \mathrm{P}=0.03632$. In Figure 14, we compare this model for population growth to the actual data. We can see that population growth, after a bulge

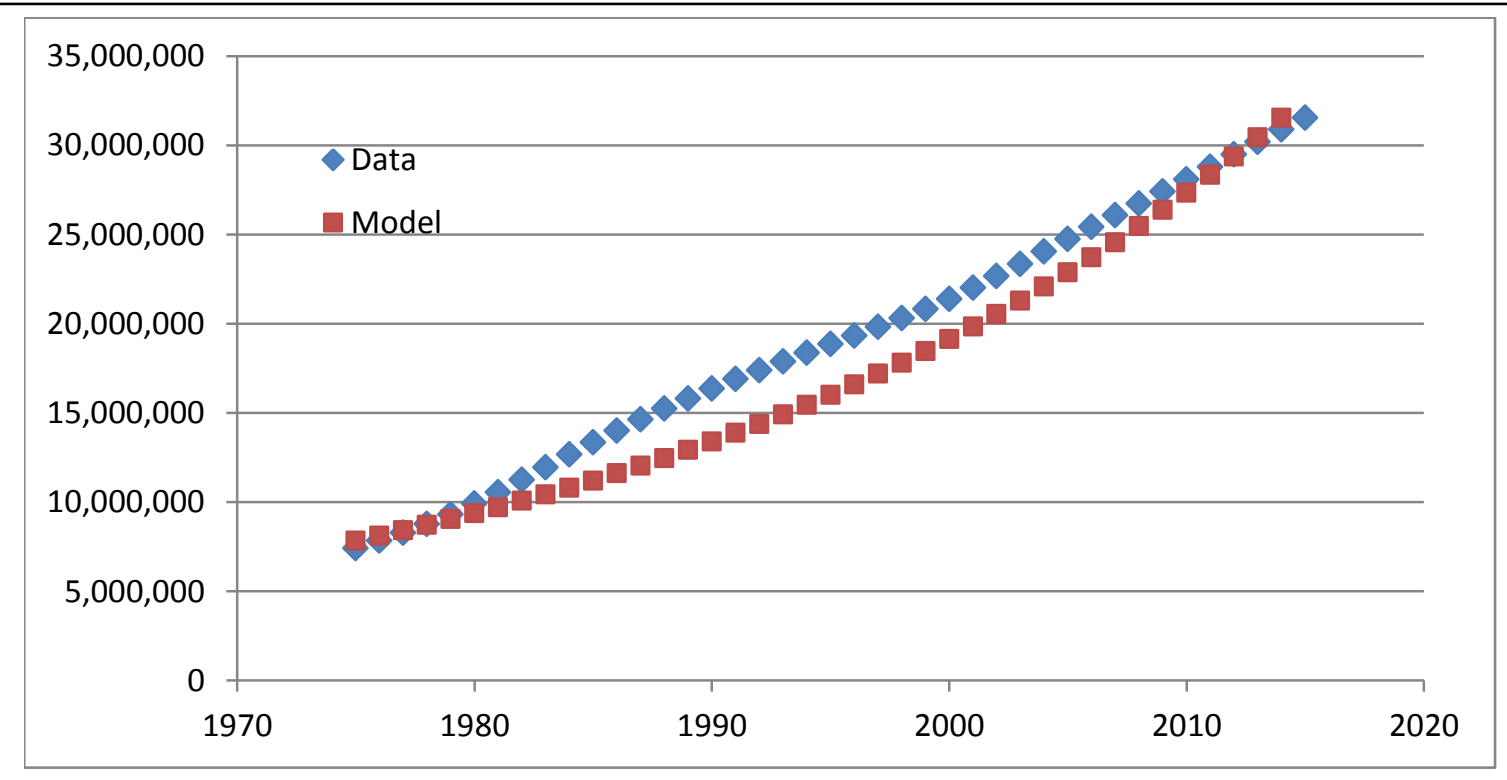

Figure 14. Comparison of a constant-yearly-growth model for population for actual population growth in Saudi Arabia. 
between about 1980 and 1995 has been more linear than exponential. Thus, this particular model will tend to predict overly large populations in the future. Extrapolating population using Equation 6, we predict a population of about 45 million in 2025 and about 64 million in 2035. Using more sophisticated techniques, taking account of more parameters, including age distribution of the population and fertility and death rates, the US Census Bureau predicts a Saudi Arabian population of only about 32 million in 2025, with a growth rate of 1.3 percent. ${ }^{12}$ That population and growth rate in 2025 would predict a 2035 population of only about 36 million.

As a final point, we revisit our discussion of the previous section - which assumed total crude oil production at a ten-year average rate of 557 million tonnes of crude oil per year - and consider when, at that production rate, all of Saudi Arabia's production must be devoted to domestic consumption only. To make a simple estimate, we assume that production remains constant. According to that simple assumption, our model predicts that domestic consumption would exceed production of 557 million tonnes of crude oil per year in about 2038, or in 22 years. Our model of constant growth rate in domestic crude oil consumption might begin to break down by then, but this at least provides a rough estimate of the sufficiency of Saudi Arabia's crude oil production. Certainly production could be expanded, or greater use could be made of natural gas or other energy sources to change the time line. In any event, our estimate here agrees with a 2011 estimate from the UK's Royal Institute of International Affairs (Chatham House), which presumably uses a similar methodology. ${ }^{13}$

Perhaps the more important point is that well before domestic consumption equals production, the reduction in the amount of crude oil that is available for sale - which constitutes a substantial fraction of the Saudi Arabian economy - will become an important issue for the Kingdom. In Figure 15, we show the ratio of our prediction of domestic crude oil consumption, based on Equation 5, to our ten-year average for crude oil production, given in Table 1 . Note that by 2025, domestic consumption rises from thirty percent of production in 2015 to fifty percent; in other words, in roughly a decade, an additional fifth of domestic production would be lost to revenue-producing export if production held constant at the ten-year average. To be sure, our consumption model could break down before then, or production may be increased (although Saudi Arabia is the second largest producer in the world, but the point is that even in the relatively near future, domestic consumption can be expected to have a noticeable impact on Saudi Arabian oil export revenues.

Presumably these considerations are at least a factor in the development of Kingdom of Saudi Arabia's Vision 2030 plan, ${ }^{14}$ which reportedly ${ }^{15}$ grew out of a McKinsey Global Institute study ${ }^{16}$ conducted for the

12 US Census Bureau, "International Programs, International Database, Demographic Overview - Custom Region - Saudi Arabia," https://www.census.gov/population/international/data/idb/region.php?N=\%20Results $\% 20 \& \mathrm{~T}=13 \& \mathrm{~A}=$ separate $\& \mathrm{RT}=0 \& \mathrm{Y}=20$ $16 \& \mathrm{R}=-1 \& \mathrm{C}=\mathrm{SA}$.

13 Glada Lahn and Paul Stevens, "Burning Oil to Keep Cool: The Hidden Energy Crisis in Saudi Arabia," Chatham House, London, 2011.

14 Kingdom of Saudi Arabia's Vision 2030 Plan, Alriyadh (Alyamamh Press, Inc., Riyadh), 25 April 2016, accessed 20 July 2016, http:// www.alriyadh.com/en/article/1149991/Kingdom-of-Saudi-Arabias-Vision-2030.

15 Adel Abdel Ghafar, "Saudi Arabia's McKinsey Reshuffle," The Brookings Institution, May 11, 2016, accessed 10 August 2016, https://www.brookings.edu/blog/markaz/2016/05/11/saudi-arabias-mckinsey-reshuffle/.

16 Gassan Al-Kibsi, Jonathan Woetzel, Tom Isherwood, Jawad Khan, Jan Mischke, and Hassan Noura, "Moving Saudi Arabia's Economy Beyond Oil,” McKinsey Global Institute, December 2015, accessed 10 August 2016, http:// http://www.mckinsey.com/global-themes/employment-and-growth/moving-saudi-arabias-economy-beyond-oil. 
Kingdom and which calls for increasing the value-added component of the oil industry (adding more down-stream processing of crude and natural gas to produce more complex products), decreased reliance on oil revenues, and reduced subsidization of domestic consumption.

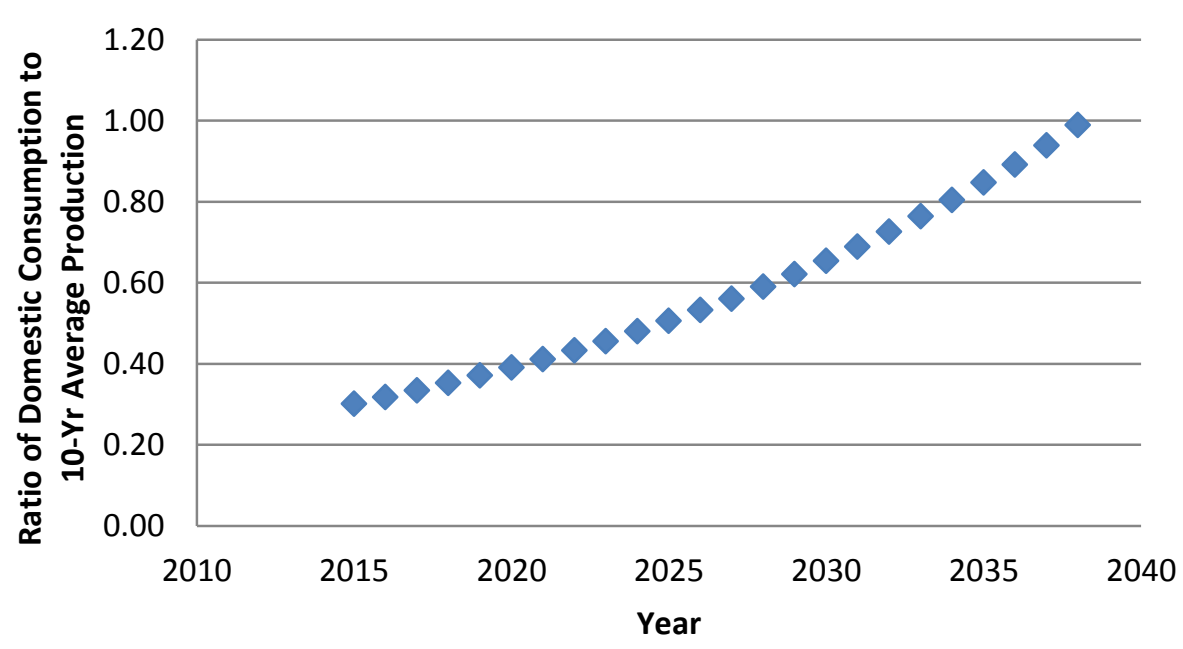

Figure 15. Ratio of Saudi Arabian domestic crude oil consumption, based on our model of Equation 5, to crude oil production, based on our ten-year average of crude oil production given in Table 1.

\section{Concluding Comments}

In this paper, we've compared energy production and consumption across the broader Middle East, paying special attention to three different countries:

- Saudi Arabia, one of the world's largest oil producers (second in the CIA World Factbook ranking of crude oil producing countries), with a growing population in the mid-range $\left(47^{\text {th }}\right.$ in the world, according to the CIA World Factbook, and fifth among the nations in this region), a large GDP and GDP per capita $\left(15^{\text {th }}\right.$ in the world, second in this region, and $21^{\text {st }}$ in GDP per capita in the world, just behind the US at $19^{\text {th }}$ ).

- Qatar, the world's fourth largest producer of natural gas, with a small native population (and a relatively large foreign labor contingent) that is very wealthy (with the world's highest GDP per capita, more than twice that of the US).

- Egypt, the most populous nation in the region (with the world's $16^{\text {th }}$ largest population), but relatively poor (with a GDP per capita of about a fifth that of the US and a twelfth that of Qatar); Egypt is a significant energy producer $-29^{\text {th }}$ in the world in crude oil production and $17^{\text {th }}$ in natural gas production - but production has stalled or declined in recent years, and domestic consumption has overtaken production.

Egypt's large population, and instability in the wake of the Arab Spring, has led to domestic energy consumption overtaking production. Further, domestic energy subsidies are limiting fossil fuel revenues and hobbling the nation's ability to increase natural gas production to attempt to catch up with domestic consumption. On the other hand, the governments of both Saudi Arabia ${ }^{17}$ and Qatar ${ }^{18}$ are concerned with

17 Kingdom of Saudi Arabia, "Vision 2030," http://vision2030.gov.sa/en, accessed 2016. 
the long-term prospects for economies that are based on finite energy resources that must be replaced with sustainable income-generating pursuits.

Nevertheless, at current rates of production, Qatar has hundreds of years of natural gas reserves. Saudi Arabia, on the other hand, with domestic crude oil consumption that has been growing for decades at a rate that has held quite constant at about 5.3 percent per year, could begin to feel an economic pinch within the next decade unless it expands its economy beyond the current dependence on crude oil sales.

18 Qatari General Secretariat for Development Planning, "Qatar National Vision 2030," file://C:/Users/c6483/Downloads/Qatar_National_Vision_2030.pdf, accessed 2016. 
SRNL-TR-2016-00309 
SRNL-STI-

Revision 0 